\title{
SECTORAL AND FIRM-LEVEL DETERMINANTS OF PROFITABILITY: A MULTILEVEL APPROACH
}

\author{
Ivana Blažková \\ Department of Regional and Business Economics \\ Mendel University in Brno \\ Brno, Czech Republic \\ blazkova@mendelu.cz \\ Ondřej Dvouletý \\ Department of Entrepreneurship \\ University of Economics, Prague \\ Praha, Czech Republic \\ ondrej.dvoulety@vse.cz
}

\begin{abstract}
The paper aimed to contribute to the literature on the determinants of firm profitability, from the perspective of the Czech economy. We followed a multilevel/hierarchical approach towards the analysis of the sectoral and firm-level determinants of the profitability of companies operating in the Czech food processing industry during years 2005-2012 (622 Firms in 10 Sectors). We assessed an impact of industry (i.e. market concentration, sector growth rate and growth rate of imports) and firm-level characteristics (i.e. market share, firm age, firm size, number of employees, debt/equity ratio and short-term risk) on the return on assets (ROA). Surprisingly, there were no substantial differences between the separate models for industry and firm-level determinants and a combined one. We found a positive impact of market concentration and market share and a negative effect of age and risk-taking behaviour on a firm profitability. Based on these findings, managers in the Czech food and drink industry should pay more attention to the debt policy.
\end{abstract}

KEYWORDS: firm profitability; return on assets (ROA); industry and firm effects; multilevel analysis; Czech food and drink industry.

JEL CLASSIFICATION: L11, L66, D22

DOI: 10.2478/IJEK-2018-0012

Received: $15^{\text {th }}$ July, 2018

1st Revision: $20^{\text {th }}$ September, 2018

Accepted: 24 ${ }^{\text {th }}$ September, 2018

Reference: Blažková, I. \& Dvouletý, O. (2018). Sectoral and firm-level determinants of profitability: A multilevel approach. International Journal of Entrepreneurial Knowledge, 6(2), 32-44. doi: 10.2478/IJEK-2018-0012

\section{INTRODUCTION}

In the current rapidly changing and global environment, quick response and adaptation to market conditions are considered to be the crucial determinants of entrepreneurial success. Business owners and managers need to very carefully study the factors that affect business performance to achieve maximisation of firm value and long-term profitability. We acknowledge there is large body of knowledge on factors impacting business performance (e.g. Hirsch et al., 2014; Setiawan et al., 2012; Lin et al., 2014; Chaddad \& Mondelli, 2013; Sauka, 2014; Daher \& Le Saout, 2015; Bamiatzi et al., 2016; Burger et al., 2017; Adámek et al., 2017; Blažková \& Dvouletý, 2018a, 2018b). However, at the same time, there are still under-researched regions, where the empirical evidence is still scarce. One of these regional research gaps are countries of Central and Eastern Europe as pointed out recently by Kocsis \& Major (2018), Gërguri-Rashiti et al. (2017), Davidova \& Gorton (2017) or Giannakis \& Bruggeman (2015). This study delivers empirical evidence to this discussion from the angle of the Czech enterprises. 
In this study, we empirically focus on the analysis of the sectoral and firm-level determinants of the performance of companies operating in the Czech food-processing industry. Generally, the food and drink industry is considered as one of the most important economic branches in the European Union (Europe, Food Drink, 2016), which is also emphasised by researchers in the field of agribusiness, e.g. Zouaghi et al. (2017) or Tong et al. (2016). According to the Czech Statistical Office (2017), the food and drink industry generated $7.5 \%$ of value added of the whole manufacturing industry, and its share on the employment in the Czech Republic was $9.2 \%$ in 2016 that makes the industry important from both economic and social perspectives.

Theoretically, there are two contradictory concepts focused on the evaluation of firm-performance determinants. The first approach is based on organisation theory (Bain, 1968), which emphasises the structural (sectoral) characteristics of the industry and the second approach, known as resource-based view (Gabreath \& Galvin, 2008), emphasises firm-specific factors of firm performance. As evidenced by numerous studies on this issue, both types of factors play a role in the explanation of firm performance variance. Although the sectoral determinants cannot be neglected (e.g. Blažková \& Dvouletý, 2018b; Chaddad \& Mondelli, 2013), the most variability of the firm performance is explained by the firm-level determinants (e.g. Goddard et al., 2009; Hirsch \& Schiefer, 2016).

Given the assumption that merging both types of determinants of firm performance in one analysis could provide us with different empirical findings and the fact that the hierarchical linear modelling is a relatively new technique in the Czech environment, we apply HLM/multilevel approach to firm-level data of the Czech food processing firms. Our goal is to estimate the impact of selected firm and sectoral determinants of profitability together. We assess the impact of industry characteristics (i.e. market concentration, sector growth rate and growth rate of imports) and the impact of firm characteristics (i.e. market share, firm age, firm size, number of employees, debt/equity and short-term risk) on the return on assets $(R O A)$ indicator.

The structure of our paper is conventional. In the following section, we briefly introduce theoretical background of our study. Further, the obtained sample, collected variables, and our empirical approach are described. The next part is dedicated to the interpretation of the obtained results. The paper ends with conclusions summarising the main findings, implications, and avenues for future research.

\section{THEORETICAL BACKGROUND}

When it comes to the previous empirical evidence in the Czech Republic, Urbancová (2018) has studied the profitability of the companies in the Czech food industry. She concluded that there are substantial differences in profitability due to the organisational structure of the sector consisting of a large number of small and micro enterprises on the one hand and several dominating large companies on the other hand. Blažková and Dvouletý (2018b) have investigated the relative importance of sectoral and firmspecific effects on firm performance. Their results led to a conclusion corresponding with majority of studies on this issue conducted in Europe (e.g. Hirsch \& Schiefer, 2016; Goddard et al., 2009; Claver et al., 2002) showing that the effects of firm-specific factors are more important (they explained around $50 \%$ of variability in firm performance) than the effects of sectoral factors (which explained only about $0.3 \%$ of variability in firm performance). Although other studies have separately investigated the role of firm-level determinants on firm performance (Blažková \& Dvouletý, 2018a) and the role of sectoral variables affecting performance in the whole sector (Blažková \& Dvouletý (2017a; 2017b), there is no study in the Czech environment that would combine both types of determinants (sectoral and firm) in one complex analysis.

Such an analysis, combining firm-level and sectoral determinants of profitability requires more sophisticated empirical approach than just a multivariate regression analysis. Scholars in the field 
conduct studies based on more than one level of analysis most often with the help of hierarchical linear modelling (HLM) approach/multilevel analysis (e.g. Wendorf et al., 2002; Huta et al., 2014 or Hox et al., 2017). Multilevel/hierarchical models have been gradually evolving since the second half of the 1980s, and have been increasingly used especially in sociological research (e.g. Liu et al., 2010; Bernard, 2011; Shen et al., 2014; Soukup, 2006), but also in economics (e.g. Ozkaya et al., 2013; Hirsch et al., 2014; Macher \& Mayo, 2015; Bamiatzi et al., 2016). This approach examines the relationships within and between the hierarchical levels of clustered data, making it more effective in detecting variations between variables at different levels better than other existing methods (Woltman et al., 2012). Nevertheless, there are also other options that might be taken into account. According to Huta (2014), the most commonly used alternatives are Structural Equation Modeling (SEM) and Generalized Linear Model (GLM) based on repeat-measured variables, for empirical examples see, e.g. Choi \& Lim (2017), Sivasubramaniam \& Kara (2015), Hair et al. (2014), Mavrogiannis et al. (2008), Wisner (2003).

\section{DATA AND METHODS}

\subsection{Sample and Data Sources}

The empirical analysis is based on micro-level data for the Czech companies operating in the Czech food and drink industry. Data were drawn from the database MagnusWeb (Bisnode, 2017). We considered only firms with complete data across the full period under study, such as Hirsch et al. (2014). Therefore, the analysis was conducted for years 2005-2012, since data availability was best for this period. Firms with the main activity in any official 3-digit CZ-NACE food processing industry were considered, i.e. ten categories between CZ-NACE 101 and CZ-NACE 110 (namely CZ-NACE 101 Production, processing, preserving of meat and meat products; CZ-NACE 102 Processing and preserving of fish and fish products; CZ-NACE 103 Processing and preserving of fruit and vegetables; CZ-NACE 104 Manufacture of vegetable and animal oils and fats; CZ-NACE 105 Manufacture of dairy products; CZ-NACE 106 Manufacture of grain mill products, starches and starch products; CZNACE 107 Manufacture of bakery and farinaceous products; CZ-NACE 108 Manufacture of other food products; CZ-NACE 109 Manufacture of prepared animal feeds; CZ-NACE 110 Manufacture of beverages). Obtained data were screened for missing or extreme values, which resulted in the sample of 622 firms with full data in 2005-2012, i.e. the data set consisted of 4,976 observations across eight years and ten Czech food processing sectors, the number of firms included in the sample differs in particular sectors. Table 1 presents the allocation of firms to ten Czech food sectors within the population and within our data sample in 2012 to assess the representativeness of the sample (within each sector, firms are also divided into four size groups according to the number of employees, i.e. firms with 0-19, 20-49, 50-249 and with 250 and more employees).

To have information on total values for particular sectors, namely total sales and imports, we employed the data published by the Ministry of Agriculture of the Czech Republic (Ministry of Agriculture of the Czech Republic, 2008, 2015). 
Table 1 Structure of the Data Sample in 2012

\begin{tabular}{|c|c|c|c|c|c|c|c|c|c|}
\hline \multirow{2}{*}{\multicolumn{2}{|c|}{ CZ-NACE }} & \multirow{3}{*}{$\begin{array}{c}\text { Population } \\
\mathrm{N} \\
1,554\end{array}$} & \multicolumn{2}{|c|}{ Sample } & \multirow{2}{*}{\multicolumn{2}{|c|}{ CZ-NACE }} & \multirow{3}{*}{\begin{tabular}{|c|} 
Population \\
$\mathrm{N}$ \\
166
\end{tabular}} & \multicolumn{2}{|c|}{ Sample } \\
\hline & & & \multirow{2}{*}{$\begin{array}{r}\mathrm{n} \\
27\end{array}$} & \multirow{2}{*}{$\begin{array}{l}\% \\
1.7\end{array}$} & & & & $\mathrm{n}$ & \multirow{2}{*}{$\frac{}{6.0}$} \\
\hline \multirow{5}{*}{101} & $0-19$ & & & & \multirow{5}{*}{106} & $0-19$ & & 10 & \\
\hline & $20-49$ & 91 & 31 & 34.1 & & $20-49$ & 22 & 10 & 45.5 \\
\hline & $50-249$ & 57 & 36 & 63.2 & & $50-249$ & 19 & 16 & 84.2 \\
\hline & $250+$ & 16 & 15 & 93.8 & & $250+$ & 0 & 0 & $\mathrm{x}$ \\
\hline & total & 1,718 & 109 & 6.3 & & total & 207 & 36 & 17.4 \\
\hline \multirow{5}{*}{102} & 0-19 & 17 & 3 & 17.6 & \multirow{5}{*}{107} & 0-19 & 2,645 & 30 & 1.1 \\
\hline & $20-49$ & 4 & 2 & 50.0 & & $20-49$ & 205 & 36 & 17.6 \\
\hline & 50-249 & 2 & 1 & 50.0 & & 50-249 & 98 & 50 & 51.0 \\
\hline & $250+$ & 1 & 0 & 0.0 & & $250+$ & 24 & 16 & 66.7 \\
\hline & total & 24 & 6 & 25.0 & & total & 2,972 & 132 & 4.4 \\
\hline \multirow{5}{*}{103} & $0-19$ & 115 & 8 & 7.0 & \multirow{5}{*}{108} & $0-19$ & 1,509 & 29 & 1.9 \\
\hline & $20-49$ & 15 & 4 & 26.7 & & $20-49$ & 58 & 26 & 44.8 \\
\hline & 50-249 & 13 & 11 & 84.6 & & 50-249 & 54 & 39 & 72.2 \\
\hline & $250+$ & 2 & 2 & 100.0 & & $250+$ & 9 & 9 & 100.0 \\
\hline & total & 145 & 25 & 17.2 & & total & 1,630 & 103 & 6.3 \\
\hline \multirow{5}{*}{104} & $0-19$ & 10 & 1 & 10.0 & \multirow{5}{*}{109} & 0-19 & 355 & 20 & 5.6 \\
\hline & $20-49$ & 3 & 2 & 66.7 & & $20-49$ & 20 & 16 & 80.0 \\
\hline & 50-249 & 5 & 3 & 60.0 & & 50-249 & 22 & 18 & 81.8 \\
\hline & $250+$ & 1 & 1 & 100.0 & & $250+$ & 5 & 5 & 100.0 \\
\hline & total & 19 & 7 & 36.8 & & total & 402 & 59 & 14.7 \\
\hline \multirow{5}{*}{105} & $0-19$ & 140 & 9 & 6.4 & \multirow{5}{*}{110} & 0-19 & 1,147 & 37 & 3.2 \\
\hline & $20-49$ & 9 & 4 & 44.4 & & $20-49$ & 29 & 21 & 72.4 \\
\hline & $50-249$ & 29 & 25 & 86.2 & & $50-249$ & 37 & 32 & 86.5 \\
\hline & $250+$ & 10 & 9 & 90.0 & & $250+$ & 9 & 8 & 88.9 \\
\hline & total & 188 & 47 & 25.0 & & total & 1,222 & 98 & 8.0 \\
\hline
\end{tabular}

(Source: European Commission, 2016; Bisnode, 2016; authors’ elaboration)

\subsection{Definition of Variables}

The data have two-level hierarchic structure - the level-1 corresponds to particular firms, and the level2 corresponds to sectors, i.e. there are lower-level units (firm-level variables) nested within higher-level units (sector level variables). The dependent variable in models is operationalized by return on assets (ROA) indicator, which measures the firm's management ability to generate profits from the firm's assets (e.g. Brealey et al., 2017), and belongs to the most commonly used measure of firm performance (Strouhal et al., 2018; Rehman, 2017; Hult et al., 2008; Richard et al., 2009). All variables used in the analysis as determinants of profitability were selected based on the availability of data and based on the previous literature (e.g. Brealey et al., 2017; Hirsch et al., 2014; Blažková \& Dvouletý, 2017a, 2017b, 2018a). Since the firm performance is influenced by the competitive environment on the market, market concentration ratio $\left(C R 4_{j}\right)$ was used to reflect the level of imperfect competition on the Czech food market. The size of the Czech food market and the demand growth is represented by the growth of sales indicator (GROWTH_SALES $)$, impact of foreign competition reflects the growth of imports (GROWTH_IMPj). According to previous research mentioned above, main firm-specific determinants 
of profitability are connected with the firm age $\left(A G E_{i j}\right)$, capital structure (in our analysis evaluated based on indebtedness, i.e. DEBT_EQUITY ${ }_{i j}$ and SHORT_RISK $K_{i j}$ ), and size of the company (in our study represented by the indicators of market share $\left(M S_{i j}\right)$, firm size $\left(S I Z E_{i j}\right)$ and number of employees $\left.\left(N U M_{-} E M P_{i j}\right)\right)$. The list of variables at the appropriate hierarchical levels is presented in Table 2, and the descriptive statistics of all variables are shown in Table 3.

Table 2 Variables at Particular Hierarchical Levels

\begin{tabular}{|c|c|c|}
\hline $\begin{array}{c}\text { Hierarchical } \\
\text { Level }\end{array}$ & Variables & Calculation of the Variable \\
\hline \multirow{3}{*}{$\begin{array}{c}\text { Level-2 } \\
\text { (Sector Level) }\end{array}$} & Market concentration $\left(C R 4_{j}\right)$ & $\sum_{i=1}^{4} M S_{i j}$ \\
\hline & Growth of sales (GROWTH_SALES $\left.S_{j}\right)$ & $\frac{\text { Sales }_{j t}-\text { Sales }_{j, t-1}}{\text { Sales }_{j, t-1}}$ \\
\hline & Growth of imports (GROWTH_IMP $)$ & $\frac{\operatorname{Imports}_{j t}-\operatorname{Imports}_{j, t-1}}{\operatorname{Imports}_{j, t-1}}$ \\
\hline \multirow{8}{*}{$\begin{array}{c}\text { Level-1 } \\
\text { (Firm Level) }\end{array}$} & Market share $\left(M S_{i j}\right)$ & $\frac{\text { Sales }_{i}}{\text { Sales }_{j}}$ \\
\hline & Firm age $\left(A G E_{i j}\right)$ & number of years the firm operates on the market \\
\hline & Firm size $\left(S I Z E_{i j}\right)$ & logarithm of total assets \\
\hline & Number of employees (NUM_EMP & $\begin{array}{c}\text { four categories according to the number of employees } \\
(0-19,20-49,50-249 \text { and } 250 \text { and more employees })\end{array}$ \\
\hline & \multirow{2}{*}{ Debt/Equity ratio $\left(D E B T_{-} E Q U I T Y_{i j}\right)$} & Total Liabilities $_{i j}$ \\
\hline & & $\overline{\text { Shareholders'Equity }_{i j}}$ \\
\hline & Short-run risk (SHORT_RISK $\left.K_{i j}\right)$ & $\frac{\text { Short-term Liabilities }_{i j}}{\text { Current } \text { Assets }_{i j}}$ \\
\hline & $\mathrm{ROA}^{*}$ & $R_{0} A_{i}=\frac{E B I T_{i}}{\text { Total Assets }_{i}}$ \\
\hline
\end{tabular}

(Source: authors' elaboration; financial indicators are defined based on Brealey et al., 2017)

Table 3 Descriptive Statistics

\begin{tabular}{|c|c|c|c|c|c|c|}
\hline Variable & Mean & Median & $\begin{array}{l}\text { Standard } \\
\text { Deviation }\end{array}$ & Minimum & Maximum & Observations \\
\hline \multicolumn{7}{|c|}{ Level-1 } \\
\hline $\mathrm{ROA}$ & 0.06 & 0.05 & 0.09 & -0.30 & 0.55 & 4,976 \\
\hline$M S$ & 0.01 & 0.00 & 0.02 & 0.00 & 0.24 & 4,976 \\
\hline$A G E$ & 13.52 & 14.96 & 4.00 & 3.76 & 18.89 & 4,976 \\
\hline SIZE & 10.89 & 10.95 & 1.85 & 5.05 & 16.69 & 4,976 \\
\hline NUM_EMP & 2.30 & 2.00 & 0.99 & 1.00 & 4.00 & 4,976 \\
\hline DEBT_EQUITY & 12.32 & 1.32 & 63.92 & 0.02 & 1006.97 & 4,976 \\
\hline SHORT_RISK & 0.85 & 0.71 & 0.80 & 0.02 & 10.66 & 4,976 \\
\hline \multicolumn{7}{|c|}{ Level-2 } \\
\hline CR4 & 0.39 & 0.35 & 0.15 & 0.21 & 0.71 & 80 \\
\hline GROWTH_SALES & 0.03 & 0.00 & 0.05 & -0.01 & 0.16 & 80 \\
\hline GROWTH_IMP & 0.08 & 0.08 & 0.03 & 0.04 & 0.15 & 80 \\
\hline
\end{tabular}

(Source: HLM7; authors' elaboration) 


\subsection{Empirical Approach}

In the following analysis, we assess the impact of industry characteristics (i.e. market concentration, sector growth rate and growth rate of imports) and the impact of firm characteristics (i.e. market share, firm age, firm size, number of employees, short-term risk and long-term risk) on the return on assets (ROA) indicator. The effects of sectoral characteristics (Level-2) and firm characteristics (Level-1) on ROA were estimated with the use of hierarchical linear modelling (HLM). The models were estimated in the software HLM7 - Hierarchical Linear and Nonlinear Modelling. For a detailed description of the logic, rationale and parameter estimation approaches behind hierarchical linear models see for example Bamiatzi et al. (2016), Raudenbush \& Bryk (2002) or Woltman et al. (2012).

As an initial step of HLM, we need to assess the differences in explained variance concerning both levels of analysis to see if we have selected suitable levels. In line with Soukup (2006), we have calculated Intra-Class Correlation Coefficient (ICC):

$I C C=\frac{\sigma_{u}^{2}}{\sigma_{e}^{2}+\sigma_{u}^{2}}$

where $\sigma_{u}$-denotes variance at the second level,

$\sigma_{e}-$ denotes variance at the first level.

Values of calculated ICC indicated that $15.5 \%$ of the variability of ROA is attributed to differences between sectors and $84.5 \%$ to differences between firms, which is in line with the previous research suggesting the greater importance of firm-specific determinants of performance in comparison with the sectoral variables (Blažková \& Dvouletý, 2018b).

The next step of the analysis was to explain the differences between firms (level 1) while respecting the information that companies are from different sectors, i.e. respecting the existence of level 2. The relationships between particular explanatory level-1 variables (see Table 2) and the outcome variable (ROA) were analysed. In order words, for each explanatory level-1 variable, we have estimated a regression coefficient (including its statistical significance) that helps us to understand the relationship between the firm-level determinants (level-1 variables) and the outcome variable of interest (ROA). Then, we did the same for the sectoral determinants (level-2 variables). Finally, we have estimated a combined model with both firm-level (level-1 variables) and sectoral (level-2 variables) to understand the merged influence of both types of determinants on ROA. The most suitable model for our data was specified based on the values of different information criteria, such as Akaike Information Criterion (AIC), Bayesian Information Criterion (BIC) and the logarithm of the likelihood function. Additionally, we have also checked for the level of collinearity, and no multicollinearity was detected in our estimates. The final model was found to be statistically significant, and all assumptions of HLM (see e.g. Raudenbush \& Bryk, 2002) were met (including independent and normal distribution of residuals and independence of level-related errors and error terms). Thus we might proceed towards the interpretation of all obtained estimates.

\section{RESULTS AND DISCUSSION}

As we have described our approach in the previous section, we first present the separate estimates for firm-level (i.e. market share, firm age, firm size, number of employees, debt/equity ratio and short-term risk) and sectoral determinants (i.e. market concentration, sector growth rate and growth rate of imports) of firm profitability operationalized by ROA in Table 4. In the second step, we merged both levels of determinants into a final reduced model that is presented in Table 5. 


\subsection{Firm and Sectoral Determinants of Profitability}

\subsubsection{Firm-level Determinants}

As seen in Table 4, the analysis proved the statistically significant positive impact of the market share (MS) on ROA. In general, the market share assesses the competitive position of the firm, as the growth of the market share of a firm usually leads to the growth of the firm's profitability (Farris et al., 2010). This idea is based on the assumption that costs are decreasing as a result of easier access to cheaper resources, companies also more often differentiate their products, and because of their better competitive position and greater market power, they can afford to set higher prices than competitors. Moreover, they can also use economies of scale due to their size. Blažková and Dvouletý (2018a) also mention that the administrative burdens within the complex EU legislation regarding food safety, additives, packaging, and labelling put heavier administrative burdens on smaller firms than on largescale firms. In the Czech agribusiness environment, food businesses are subject to strong pressure from the downstream vertical stage, i.e. trade, which is significantly concentrated (as documented by Blažková, 2016); therefore, the larger market share of the food company is an important factor that positively affects the profitability of firms in the Czech food industry.

Firm age can generally explain the effects of the business life cycle. It is usually expected that the costs will decrease with the increasing age of the company as a result of the learning effect, which will lead to higher profits for older and "more mature" companies (Ericson \& Pakes, 1995). On the other hand, ageing may lead to the loss of flexibility within the rapidly changing environment, to the organisational rigidity, and slower growth, stated by Sørensen \& Stuart (2000) and Hirsch et al. (2014). Therefore, it is not entirely clear whether ageing helps firms to thrive, or rather negatively influences their performance. The findings of our analysis confirm the negative relationship between firm age (AGE) and ROA in the Czech food processing industry, which is in line with the findings of Hirsch et al. (2014).

The results in Table 4 show that the size of the company has a positive impact on the performance of the Czech food processing firms in the observed period, which is confirmed by both size (SIZE) and employees category (NUM_EMP). Since price competition is one of the main competitive strategies among food processors, achieving economies of scale due to sufficient firm size seems to be a significant factor of the firm's profitability. Also, large firms tend to be more successful on the market due to the prevailing market power of highly concentrated retail, as also found by Blažková \& Dvouletý (2018a).

Two variables were used to assess the indebtedness and risk behaviour of the Czech food enterprises DEBT_EQUITY and SHORT_RISK, which confirmed the negative relationship between risk and profitability in the Czech food industry. The similar findings were also obtained in studies by Hirsch $e t$ al. (2014), Asimakopoulos et al. (2009) or Blažková \& Dvouletý (2018a).

\subsubsection{Sectoral Determinants}

The sectoral market concentration can generally be expected to have a significant impact on firm profitability. Companies in highly concentrated industries may have the ability to prevent entry into the industry, leading to higher profits (Newmark, 2004; Setiawan et al., 2012; Hirsch et al., 2014). Also, better bargaining positions of large food firms can be expected due to the highly concentrated downstream vertical level, i.e. retail (Blažková, 2016). The analysis confirmed the significant effect of market concentration (CR4) on profitability $(R O A)$ of the Czech food enterprises.

The results in Table 4 show that the increase in growth of the sector (measured by GROWTH_SALES) led to higher profitability of the Czech food processing firms. If the industry 
grows due to the growth in demand, companies in the industry can achieve higher profits by increasing the volume of output sold or higher prices, so higher profitability can be expected.

As seen in Table 4, with the increasing rate of imports (IMP), the negative impact on the profitability $(\mathrm{RO} A)$ of domestic enterprises is evident, as competition on the market and the downward pressure on prices are increasing.

Table 4 Firm and sector determinants of profitability (Dependent variable is ROA)

\begin{tabular}{|c|c|c|}
\hline Independent Variable & Coefficient & Standard Error \\
\hline Constant & $0.0597 * * *$ & $(0.0120)$ \\
\hline \multicolumn{3}{|c|}{ Level-1 (Firm-level Determinants) } \\
\hline$M S$ & $0.7787 * * *$ & $(0.1487)$ \\
\hline$A G E$ & $-0.0022^{* * *}$ & $(0.0008)$ \\
\hline SIZE & $0.0048^{* *}$ & $(0.0018)$ \\
\hline NUM_EMP & $0.0088^{* * *}$ & $(0.0033)$ \\
\hline DEBT_EQUITY & $-0.0002^{* * *}$ & $(0.0001)$ \\
\hline SHORT_RISK & $-0.0262^{* * *}$ & $(0.0041)$ \\
\hline \multicolumn{3}{|c|}{ Level-2 (Sectoral Determinants) } \\
\hline CR4 & $0.3510^{* * *}$ & $(0.0848)$ \\
\hline GROWTH_SALES & $1.0687 * * *$ & $(0.2409)$ \\
\hline GROWTH_IMP & $-0.9121 * * *$ & $(0.2036)$ \\
\hline
\end{tabular}

(Source: HLM7; authors' elaboration)

\subsection{Final Reduced Model including Merged Determinants of Profitability}

Finally, we have estimated a combined model with both firm-level (level-1) variables and sectoral (level2) variables. The model is presented in Table 5 below. The information criteria drove the selection process, and we have ended up with the four firm-level variables (market share, firm age, short-term risk and debt/equity ratio) and one sectoral variable (market concentration). The previous section showed that all obtained estimates have an economic logic, and so do the findings obtained from the merged model have. Initially, we do not see large differences in comparison with the previously presented (separate) models.

Table 5 A Combined model of Firm and Sectoral determinants of Profitability (Dependent variable is $\mathrm{ROA}$ )

\begin{tabular}{|l|c|c||}
\hline \multicolumn{1}{|c|}{ Independent Variable } & Coefficient & Standard Error \\
\hline Constant & $0.0648^{* * *}$ & $(0.0073)$ \\
\hline CR4 & $0.3410^{* * *}$ & $(0.0861)$ \\
\hline$M S$ & $0.8395^{* * *}$ & $(0.1427)$ \\
\hline AGE & $-0.0025^{* * *}$ & $(0.0041)$ \\
\hline SHORT_RISK & $-0.0238^{* * *}$ & $(0.0001)$ \\
\hline DEBT_EQUITY & $-0.0002^{* * *}$ & . \\
\hline Note: $* * *$ stat. significance at $1 \%$ level, $* *$ stat. significance at $5 \%, *$ stat. significance at $10 \%$. Number of \\
\hline
\end{tabular}


Firms $=622$ (i.e.: 4,976 Observations), Number of Sectors $=10$ (i.e.: 80 Observations).

(Source: HLM7; authors' elaboration)

The results show the positive impact of the sectoral market concentration (CR4) on $R O A$. As mentioned above, there are more possible explanations for this observation. One may think of a better bargaining position with customers, the use of economies of scale, better access to capital enabling large companies to use better and new technologies, product diversification and easier deployment of innovations.

From the firm-level perspective, market share (MS), indicates the idea mentioned above that more concentrated industry can achieve higher profitability. The combined model also confirmed the negative impact of firm age ( $A G E$ ) on $R O A$ - younger firms are likely to respond faster to changes in demand, which may be a more important factor than experience and savings due to the "learning" effect of older firms in the Czech food processing industry.

In spite of the risk theory (Roeser, 2012; Tsai \& Luan, 2016), which suggests that higher-risk companies should achieve higher profits on average, the variables characterizing the risk, both short-term risk and debt/equity ratio (SHORT_RISK and DEBT_EQUITY), in the estimated model have a statistically significant negative impact on $\mathrm{RO} A$ - high-risk financing of activities led to lower profitability of food companies in the Czech Republic during the analysed period.

\section{CONCLUSIONS}

The paper aimed to contribute to ongoing research on the determinants of the firm profitability, from the perspective of an under-researched Czech economy. The previous researchers have turned attention towards the role of country, industry and firm-level determinants of profitability solely, however not many scholars have studied the impact of these determinants together. In this study, we have employed a multilevel/hierarchical approach towards the analysis of the sectoral and firm-level determinants of the performance of companies operating in the Czech food processing industry during years 2005-2012. Our goal was to investigate the impact of selected firm and sectoral determinants of profitability together. Particularly, we assessed the impact of industry characteristics (i.e. market concentration, sector growth rate and growth rate of imports) and the impact of firm characteristics (i.e. market share, firm age, firm size, number of employees, short-term risk and debt/equity ratio) on the return on assets $(R O A)$ indicator.

We have separately analysed both types of effects, and then we have merged both levels of variables in a one multilevel-model. Surprisingly, there were no substantial differences between separate models and a merged one. The results showed that market concentration had during the analysed period positive impact on the firm-level profitability. This confirms the assumption that firms in high-concentrated sectors may have better opportunities to prevent new firms from entering the industry, leading to higher profits, as well as better negotiating position for food processors with the highly concentrated retail. Once we had a look at the firm-level determinants of profitability, we found a positive relationship between the company's market share and profitability which may be due to factors such as the use of economies of scale, better access to capital for larger firms, more qualified management or better market position when dealing with business partners. It follows from the analysis that younger food firms reached higher profitability in the monitored period, which is likely due to their ability respond quickly to changing market conditions. We have also found a negative relationship between the risk-taking behaviour (both short-term and long-term) and profitability.

The presented analysis offers implications for both entrepreneurs and policymakers. From the managerial viewpoint, agribusiness firms should base their strategies on differentiation from 
competitors and seek market opportunities, which are important means of achieving higher market share and profitability. Due to the dynamic development of the global environment, not only experience but especially know-how and flexibility are important characteristics of success, which emphasises the need to employ high-skilled managers and employees. We have also found the negative impact of indebtedness on the firm profitability of the Czech food processing firms in the monitored period. Therefore, managers should pay attention to the debt policy, since high indebtedness worsens the competitive position of the Czech food processing firms on the market and contributes to a decline in their credibility. From the viewpoint of economic policy, special attention should be paid to market power assessment, merger approval both in the food processing industry and in the retail sector, and valuation of price relations within commodity verticals, i.e. between farmers, processors and retail, in order to ensure a competitive environment within the whole agribusiness sector.

Our analysis also provides a basis for at least two propositions for further empirical research focused on firm performance and its determinants. The first extension of our research should be the investigation of further firm-level determinants of profitability, such as e.g. R\&D activities or expenditures on advertising. The second recommendation for future research is to include more hierarchical levels (such as e.g. country level) in the analysis. However, the main issue we would like to mention is the importance of data availability both at the firm and sectoral level, which is a crucial limitation for research community when conducting comprehensive hierarchical analyses such as this one.

\section{ACKNOWLEDGEMENT}

This work was supported by Internal Grant Agency of Faculty of Business Administration, University of Economics in Prague, under no.: IP300040, and by Internal Grant Agency of Faculty of Regional Development and International Studies, Mendel University in Brno, under no.: 2018/004. An earlier version of the paper was presented at the XI. International Conference on Applied Business Research, held in Pattaya City (Thailand) in September, 2016.

\section{REFERENCES}

Adámek, P., Bauerová, R., Kadlubcová, J., \& Zapletalová, Š. (2017). The Business Excellence Models in Czech Enterprises: The Effects of Business Strategy on Performance. Central European Business Review, 6(4), 20-29.

Asimakopoulos, I., Samitas, A., \& Papadogonas, T. (2009). Firm-specific and economy wide determinants of firm profitability: Greek evidence using panel data. Managerial Finance, 35(11), 930-939.

Bain, J. S. (1968). Industrial Organization. $2^{\text {nd }}$ Edition. Wiley, New York.

Bamiatzi, V., Bozos, K., Cavusgil, S. T., \& Hult, G. T. M. (2016). Revisiting the firm, industry, and country effects on profitability under recessionary and expansion periods: A multilevel analysis. Strategic management journal, 37(7), 1448-1471.

Bernard, J. (2011). Endogenní rozvojové potenciály malých venkovských obcí - obtížné hledání a měření jejich vlivu. Sociologický ćasopis/Cz̨ech Sociological Review, 47(04), 745-775.

Bisnode (2017). MagnusWeb. Bisnode Česká republika, a.s. Retrieved from https://magnusweb.bisnode.cz/ (Consulted: 05 April 2017).

Blažková, I. (2016). Convergence of Market Concentration: Evidence from Czech Food Processing Sectors. AGRIS on-line Papers in Economics and Informatics, 8(4), 25-36.

Blažková, I., \& Dvouletý, O. (2017a). Is the price-cost margin affected by the market concentration? Evidence from the Czech food and beverages industry. Business and Economic Horizons, 13(2), 256269. 
Blažková, I., \& Dvouletý, O. (2017b). Drivers of ROE and ROA in the Czech Food Processing Industry in the Context of Market Concentration. AGRIS on-line Papers in Economics and Informatics, 9(3), 3-14.

Blažková, I., \& Dvouletý, O. (2018a). Investigating the Differences in Entrepreneurial Success through the Firm-specific Factors: Microeconomic Evidence from the Czech Food Industry. Journal of Entrepreneurship in Emerging Economies (in print).

Blažková, I., \& Dvouletý (2018b). The causes of firm performance variation in the Czech food processing industry in the context of the outlier effect. Management Research Review, 41(8), 968-986.

Brealey, R., Myers, S., \& Allen, F. (2017). Principles of Corporate Finance. 12th Edition, McGraw-Hill Education.

Burger, A., Damijan, J. P., Kostevc, Č., \& Rojec, M. (2017). Determinants of firm performance and growth during economic recession: The case of Central and Eastern European countries. Economic Systems, 41(4), 569-590.

Chaddad, F. R., \& Mondelli, M. P. (2013). Sources of Firm Performance Differences in the US Food Economy. Journal of Agricultural Economics, 64(2), 382-404.

Claver, E., Molina, J., \& Tarí, J. (2002). Firm and Industry Effects on Firm Profitability: a Spanish Empirical Analysis. European Management Journal, 20(3), 321-328.

Czech Statistical Office (2017). Statistical Yearbook of the Czech Republic 2017. Retrieved from https://www.czso.cz/csu/czso/statistical-yearbook-of-the-czech-republic (Consulted: 10 March 2018).

Daher, L., \& Le Saout, E. (2015). The Determinants of the Financial Performance of Microfinance Institutions: Impact of the Global Financial Crisis. Strategic Chance, 24(2), 131-148.

Davidova, S., \& Gorton, M. (2017). Integration with the European Union and the Competitiveness of the Bulgarian Agro-Food Sector. In Agriculture and East-west European Integration (135-170). Routledge.

Ericson, R., \& Pakes, A. (1995). Markov-perfect industry dynamics: A framework for empirical work. Review of Economic Studies, 62(1), 53-82.

European Commission (2016). Eurostat. Structural Business Statistics. Retrieved from http://ec.europa.eu/eurostat/data/database (Consulted: 8 November 2016).

Farris, P. W., Bendle, N., Pfeifer, P., \& Reibstein, D. (2010). Marketing metrics: The definitive guide to measuring marketing performance. Pearson Education.

FoodDrink Europe (2016). Data \& trends of the European food and drink industry 2016. Confederation of the Food and Drink Industries of the EU, Brussels, Belgium. Retrieved from

http://www.fooddrinkeurope.eu/uploads/publications_documents/Data_and_trends_Interactiv e_PDF.pdf (Consulted: 10 November 2016).

Gërguri-Rashiti, S., Ramadani, V., Abazi-Alili, H., Dana, L. P., \& Ratten, V. (2017). ICT, innovation and firm performance: the transition economies context. Thunderbird International Business Review, 59(1), 93-102.

Giannakis, E., \& Bruggeman, A. (2015). The highly variable economic performance of European agriculture. Land Use Policy, 45, 26-35.

Goddard, J. A., Tavakoli, M., \& Wilson, J. O. S. (2009). Sources of variation in firm profitability and growth. Journal of Business Research, 62(4), 495-508.

Hair Jr, J. F., Sarstedt, M., Hopkins, L., \& G. Kuppelwieser, V. (2014). Partial least squares structural equation modeling (PLS-SEM) An emerging tool in business research. European Business Review, 26(2), 106-121.

Hirsch, S., \& Schiefer, J. (2016). What Causes Firm Profitability Variation in the EU Food Industry? A Redux of Classical Approaches of Variance Decomposition. Agribusiness, 32(1), 79-92.

Hirsch, S., Schiefer, J., Gschwandtner, A., \& Hartmann, M. (2014). The determinants of firm profitability differences in EU food processing. Journal of Agricultural Economics, 65(3), 703-721.

Hox, J. J., Moerbeek, M., \& van de Schoot, R. (2017). Multilevel analysis: Techniques and applications. Routledge. 
Hult, G. T. M., Ketchen, D. J., Griffith, D. A., Chabowski, B. R., Hamman, M. K., Dykes, B. J. \& Cavusgil, S. T. (2008). An assessment of the measurement of performance in international business research. Journal of International Business Studies, 39(6), 1064-1080.

Huta, V. (2014). When to use hierarchical linear modelling. Quant Methods Psychol, 10(1), 13-28.

Choi, Y. S., \& Lim, U. (2017). Contextual factors affecting the innovation performance of manufacturing SMEs in Korea: A structural equation modelling approach. Sustainability, 9(7), 1193.

Kocsis, J., \& Major, K. (2018). A General Overview of Agriculture and Profitability in Agricultural Enterprises in Central Europe. In Managing Agricultural Enterprises (243-265). Palgrave Macmillan, Cham.

Lin, F. J., Chen, Y. M., \& Lo, F. Y. (2014). The persistence of economic profit. International Entrepreneurship and Management Journal, 10(4), 767-780.

Liu, O. L., Lee, H. S., \& Linn, M. C. (2010). An investigation of teacher impact on student inquiry science performance using a hierarchical linear model. Journal of Research in Science Teaching, 47(7), 807-819.

Macher, J. T., \& Mayo, J. W. (2015). Influencing public policymaking: Firm-, industry-, and country-level determinants. Strategic Management Journal, 36(13), 2021-2038.

Mavrogiannis, M., Bourlakis, M. A., Dawson, P. J., \& Ness, M. R. (2008). Assessing export performance in the Greek food and beverage industry: An integrated structural equation model approach. British Food Journal, 110(7), 638-654.

Ministry of Agriculture of the Czech Republic (2008). Panorama potravinářského průmyslu 2007. Retrieved from http://eagri.cz/public/web/mze/potraviny/publikace-a-dokumenty/panoramapotravinarskeho-prumyslu/panorama-potrav-prumyslu-2007.html (Consulted: 23 March 2015).

Ministry of Agriculture of the Czech Republic (2015). Panorama potravinářského průmyslu 2014. Retrieved from http://eagri.cz/public/web/mze/potraviny/publikace-a-dokumenty/panoramapotravinarskeho-prumyslu/panorama-potravinarskeho-prumyslu-2013.html (Consulted: 10 June 2015).

Newmark, C. M. (2004). Price-concentration Studies: There You Go Again. Retrieved from https://www.researchgate.net/profile/Craig_Newmark/publication/251710681_PriceConcentration_Studies_There_You_Go_Again (Consulted: 25 March 2016).

Ozkaya, H. E., Dabas, C., Kolev, K., Hult, G. T. M., Dahlquist, S. H., \& Manjeshwar, S. A. (2013). An assessment of hierarchical linear modeling in international business, management, and marketing. International Business Review, 22(4), 663-677.

Raudenbush, S. W., \& Bryk, A. S. (2002). Hierarchical linear models: Applications and data analysis methods (Vol. 1). Sage.

Rehman, O. U. (2017). Firms' Aggressiveness and Respective Performance: An Empirical Study under Pakistani Scenery. International Journal of Entrepreneurial Knowledge, 5(1), 5-19.

Richard, P. J., Devinney, T. M., Yip, G. S., \& Johnson, G. (2009). Measuring organizational performance: Towards methodological best practice. Journal of Management, 35(3), 718-804.

Roeser, S. (2012). Handbook of risk theory: Epistemology, decision theory, ethics, and social implications of risk. Springer Science \& Business Media.

Sauka, A. (2014). Measuring the competitiveness of Latvian companies. Baltic Journal of Economics, 14(12), $140-158$.

Setiawan, M., Emvalomatis, G., \& Lansink, A. O. (2012). Industrial concentration and price-cost margin of the Indonesian food and beverages sector. Applied Economics, 44(29), 3805-3814.

Shen, J., Washington, A. L., Bierlein Palmer, L., \& Xia, J. (2014). Effects of traditional and nontraditional forms of parental involvement on school-level achievement outcome: An HLM study using SASS 2007-2008. The Journal of Educational Research, 107(4), 326-337.

Sivasubramaniam, N., \& Kara, A. (2015). A Structural Equation Model of the Relationship between Advertising, Profitability and Size. In Proceedings of the 1993 Academy of Marketing Science (AMS) Annual Conference, 547-552, Springer International Publishing.

Sørensen, J. B., \& Stuart, T. E. (2000). Aging, obsolescence, and organizational innovation. Administrative science quarterly, 45(1), 81-112. 
Soukup, P. (2006). Proč užívat hierarchické lineární modely? Sociologický časopis/Czech Sociological Review, 42(05), 987-1012.

Strouhal, J., Štamfestová, P., Ključnikov, A., \& Vincúrová, Z. (2018). Different Approaches to the EBIT Construction and their Impact on Corporate Financial Performance Based on the Return on Assets: Some Evidence from Czech TOP100 Companies. Journal of Competitiveness, 10(1), 144154.

Tong, T., Yu, T. E., Jensen, K., De La Torre Ugarte, D., \& Cho, S. H. (2016). Impact of Public Infrastructure on Output of US Food Manufacturing Industries: A Heterogeneous Dynamic Panel Approach. Agribusiness, 32(4), 439-453.

Tsai, H. F., \& Luan, C. J. (2016). What makes firms embrace risks? A risk-taking capability perspective. BRQ Business Research Quarterly, 19(3), 219-231.

Urbancová, H. (2018). Profitability in Czech Agricultural Enterprises. In Managing Agricultural Enterprises (133-144). Palgrave Macmillan, Cham.

Wendorf, C. A. (2002). Comparisons of structural equation modeling and hierarchical linear modeling approaches to couples' data. Structural Equation Modelling, 9(1), 126-140.

Wisner, J. D. (2003). A structural equation model of supply chain management strategies and firm performance. Journal of Business Logistics, 24(1), 1-26.

Woltman, H., Feldstain, A., MacKay, J. C., \& Rocchi, M. (2012). An introduction to hierarchical linear modelling. Tutorials in Quantitative Methods for Psychology, 8(1), 52-69.

Zouaghi, F., Sánchez-García, M., \& Hirsch, S. (2017). What drives firm profitability? A multilevel approach to the Spanish agri-food sector. Spanish Journal of Agricultural Research, 15(3), e0117. 